\title{
Thermal effect of holmium laser during ureteroscopic lithotripsy
}

\author{
Hui Liang ${ }^{*}$, Lijian Liang, Yin Yu, Bin Huang, Jia'nan Chen, Chaoguo Wang, Zhangguo Zhu and Xiaozhong Liang
}

\begin{abstract}
Background: Holmium laser lithotripsy is the most common technique for the management of ureteral stone. Studies founded that holmium laser firing can produce heat which will cause thermal injury towards ureter. The aim of our current study is to explore factors affecting thermal effect of holmium laser during ureteroscopic lithotripsy.

Methods: An in vitro experimental model is design to simulate the ureteroscopic lithotripsy procedure. Different laser power settings $(10 \mathrm{w}(0.5 \mathrm{JX} 20 \mathrm{~Hz}, 1.0 \mathrm{JX} 10 \mathrm{~Hz}), 20 \mathrm{w}(1.0 \mathrm{JX} 20 \mathrm{~Hz}, 2.0 \mathrm{JX} 10 \mathrm{~Hz}), 30 \mathrm{w}(1.5 \mathrm{JX} 20 \mathrm{~Hz}, 3.0 \mathrm{JX} 10 \mathrm{~Hz}))$ with various firing time $(3 \mathrm{~s}, 5 \mathrm{~s}, 10 \mathrm{~s})$ and irrigation flow rates $(10 \mathrm{ml} / \mathrm{min}, 15 \mathrm{ml} / \mathrm{min}, 20 \mathrm{ml} / \mathrm{min}$ and $30 \mathrm{ml} / \mathrm{min}$ ) were employed in the experiment. The temperature around the laser tip was recorded by thermometer.
\end{abstract}

Results: The temperature in the "ureter" rises significantly with the increasing laser power, prolonging firing time and reducing irrigation flow. The highest regional temperature is $78.0^{\circ} \mathrm{C}$ at the experimental set-up, and the lowest temperature is $23.5^{\circ} \mathrm{C}$. Higher frequency setting produces more heat at the same power. Laser power $<=10 \mathrm{w}$, irrigation flow $>=30 \mathrm{ml} / \mathrm{min}$ and "high-energy with low-frequency" can permit a safe working temperature.

Conclusion: We clarify that the thermal effect of holmium laser is related with both laser working parameters and irrigation flow. The proper setting is the key factor to ensure the safety during ureteroscopic holmium laser lithotripsy.

Keywords: Holmium laser, Thermal effect, Lithotripsy

\section{Background}

Ureteral calculus is a common urological entity which is usually managed by ureteroscopic lithotripsy. The Holmium:YTTRIUM-ALUMINUM-GARNET (Ho:YAG) laser is the most efficient and versatile modality for ureteroscopic management of ureteral calculus [1]. Holmium laser's safety profile has been previously shown to be favorable compared to other lithotrites, since the 2100-nm wavelength of the Ho:YAG laser permits rapid absorption in water and thereby limits the depth of penetration and surrounding tissue injury. However, with the widely application of Ho:YAG laser, complications entailed by ureteroscopy such as ureteral stricture become common. It is reported that post-ureteroscopy

\footnotetext{
* Correspondence: urolianghui@163.com

Department of Urology, Xinchang County Hospital of Traditional Chinese Medicine, Shaoxing, Zhejiang Province, China
}

ureteral stricture can be as high as $1-4 \%$ [2]. The potential cause of stricture is more likely to be the direct thermal injury towards the ureteral wall rather than acoustic or photonic energy [3]. Laser energy can produce heat and potentially cause thermal bioeffects [4-7]. In our current study, we aim to characterize the relationship between working parameter and intra-ureteral temperatures during ureteroscopic holmium lithotripsy.

\section{Methods}

An in vitro model mimicking ureteroscopic laser lithotripsy was established to assess the temperature changes during laser discharge. A segment of ligated F20 rubber tube was used to simulating human ureter with stone impaction. The lithotripsy laser system was used with the 200um laser fiber passed through the working channel of a F8/9.8 ureteroscope (Fig. 1). Raykeen Holmium laser (Raykeen, Shanghai, China) was applied in the

(c) The Author(s). 2020 Open Access This article is licensed under a Creative Commons Attribution 4.0 International License, which permits use, sharing, adaptation, distribution and reproduction in any medium or format, as long as you give appropriate credit to the original author(s) and the source, provide a link to the Creative Commons licence, and indicate if changes were made. The images or other third party material in this article are included in the article's Creative Commons licence, unless indicated otherwise in a credit line to the material. If material is not included in the article's Creative Commons licence and your intended use is not permitted by statutory regulation or exceeds the permitted use, you will need to obtain permission directly from the copyright holder. To view a copy of this licence, visit http://creativecommons.org/licenses/by/4.0/ The Creative Commons Public Domain Dedication waiver (http://creativecommons.org/publicdomain/zero/1.0/) applies to the data made available in this article, unless otherwise stated in a credit line to the data. 


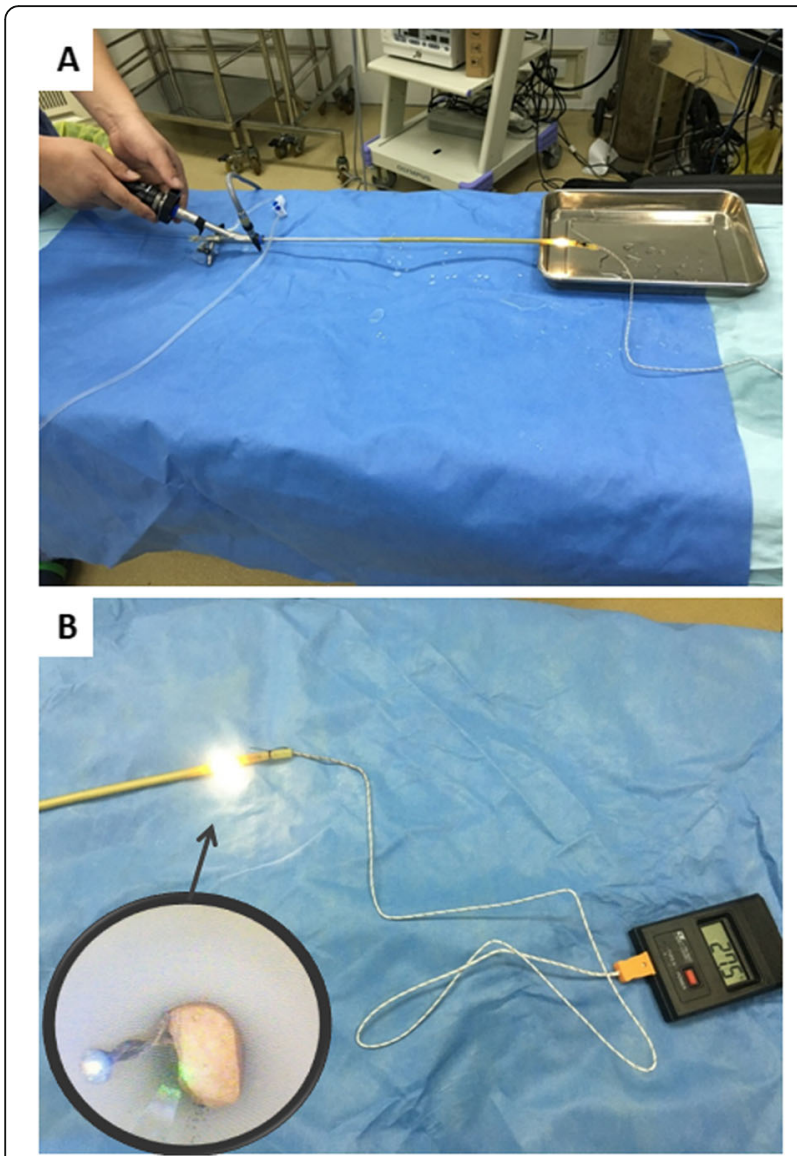

Fig. 1 a A simulated ureteroscopic laser lithotripsy procedure was established within a rubber tube. b Regional temperature was recorded by thermocouple

experiment with the various power settings commonly used in clinical practice. Energy settings were 0.5, 1.0, 1.5 and $2.0 \mathrm{~J}$. Frequency settings of 10 and $20 \mathrm{~Hz}$ were tested at different energy settings. Laser firing time was $3 \mathrm{~s}, 5 \mathrm{~s}$ and $10 \mathrm{~s}$. The relevant irrigation flow rates of 10 $\mathrm{ml} / \mathrm{min}, \quad 15 \mathrm{ml} / \mathrm{min}, 20 \mathrm{ml} / \mathrm{min}$ and $30 \mathrm{ml} / \mathrm{min}$ were employed by infusion pump at room temperature. A thermocouple was held $5 \mathrm{~mm}$ from the bottom and approximately $2 \mathrm{~mm}$ lateral from the position of the laser tip to record temperature. The temperature for each power and irrigation setting combination was recorded five times, and means were calculated for statistical comparison in different setup.

\section{Results}

Heat accumulated around the laser fiber tip. The temperature data was summarized in Table 1 . The temperature rises with the increasing laser power and firing time. Adequate irrigation flow can carry the heat away. The peak temperature, $78.0^{\circ} \mathrm{C}$, occurred with continuous laser firing for $10 \mathrm{~s}$ at the power setting of $1.5 \mathrm{JX} 20 \mathrm{~Hz}$ and irrigation flow rate $10 \mathrm{ml} / \mathrm{min}$. While the lowest temperature, $25.3^{\circ} \mathrm{C}$, was captured after continuous laser firing for $3 \mathrm{~s}$ at the power setting of $1.0 \mathrm{JX} 10 \mathrm{~Hz}$ and irrigation flow rate $30 \mathrm{ml} / \mathrm{min}$.

For the power setting of $10 \mathrm{w}$, the temperature remains more stable irrespective of laser firing time or irrigation flow rate. When the power reaches $20 \mathrm{w}$, the temperatures rapidly rise if irrigation is insufficient. Adequate irrigation or shorter laser firing time will be required to restrict the temperature. Figure 2 depicts temperature tracings for trials with different laser settings at 4 different irrigation flow rates. Another interesting finding is that for the same power setting, the "high-energy with low-frequency" parameter generates less thermal effect. The mean temperature difference is more evident when the irrigation is insufficient.

\section{Discussion}

Holmium laser is the most powerful energy tool for stone fragmentation during ureteroscopic lithotripsy [8]. Even though it is regarded as a minimally invasive surgical approach, it still brings troublesome complication, such as ureteral stricture [9]. Ureteral stricture is one of common complication post ureteroscopic surgery, especially for the impacted ureteral stone [9]. Previously, mechanical injury is considered as the main cause for ureteral stricture. However, more and more evidence indicates ureteral stricture can also occur even without mechanical injury. The issue of the intra-opertative holmium laser thermal effect has gradually gained attention

Table 1 Regional temperature changes with different laser working models and irrigation flow rates

\begin{tabular}{|c|c|c|c|c|c|c|c|c|c|c|c|c|c|}
\hline \multirow[t]{2}{*}{ Power } & \multirow{2}{*}{$\begin{array}{l}\text { Flow rates } \\
\text { Firing Time }\end{array}$} & \multicolumn{3}{|c|}{$10 \mathrm{ml} / \mathrm{min}$} & \multicolumn{3}{|c|}{$15 \mathrm{ml} / \mathrm{min}$} & \multicolumn{3}{|c|}{$20 \mathrm{ml} / \mathrm{min}$} & \multicolumn{3}{|c|}{$30 \mathrm{ml} / \mathrm{min}$} \\
\hline & & $3 s$ & $5 s$ & $10 \mathrm{~s}$ & $3 \mathrm{~s}$ & $5 \mathrm{~s}$ & $10 \mathrm{~s}$ & $3 s$ & $5 s$ & $10 \mathrm{~s}$ & $3 s$ & $5 s$ & $10 \mathrm{~s}$ \\
\hline \multirow[t]{2}{*}{$10 w$} & $0.5 \mathrm{~J}, 2 \mathrm{HZ}$ & 32.0 & 34.9 & 34.3 & 29.6 & 28.4 & 32.0 & 29.7 & 30.8 & 31.4 & 28.2 & 28.0 & 28.7 \\
\hline & $1.0 \mathrm{~J}, 10 \mathrm{HZ}$ & 30.6 & 31.9 & 30.8 & 29.0 & 29.6 & 30.3 & 28.8 & 28.6 & 29.8 & 25.3 & 26.1 & 26.4 \\
\hline \multirow[t]{2}{*}{$20 w$} & $1.0 \mathrm{~J}, 20 \mathrm{HZ}$ & 56.3 & 65.2 & 73.5 & 42.2 & 54.6 & 56.2 & 37.9 & 39.4 & 39.5 & 35.4 & 36.5 & 36.1 \\
\hline & $2.0 \mathrm{~J}, 10 \mathrm{HZ}$ & 45.3 & 47.3 & 55.0 & 36.5 & 40.4 & 48.9 & 34.0 & 34.3 & 35.5 & 31.8 & 31.4 & 32.1 \\
\hline \multirow[t]{2}{*}{$30 w$} & $1.5 \mathrm{~J}, 20 \mathrm{HZ}$ & 63.1 & 67.3 & 78.0 & 55.6 & 58.2 & 59.9 & 44.7 & 48.2 & 52.3 & 34.5 & 37.4 & 38.8 \\
\hline & $3.0 \mathrm{~J}, 10 \mathrm{HZ}$ & 55.8 & 57.5 & 55.5 & 39.7 & 47.9 & 51.8 & 37.5 & 40.5 & 41.9 & 30.7 & 32.9 & 34.9 \\
\hline
\end{tabular}




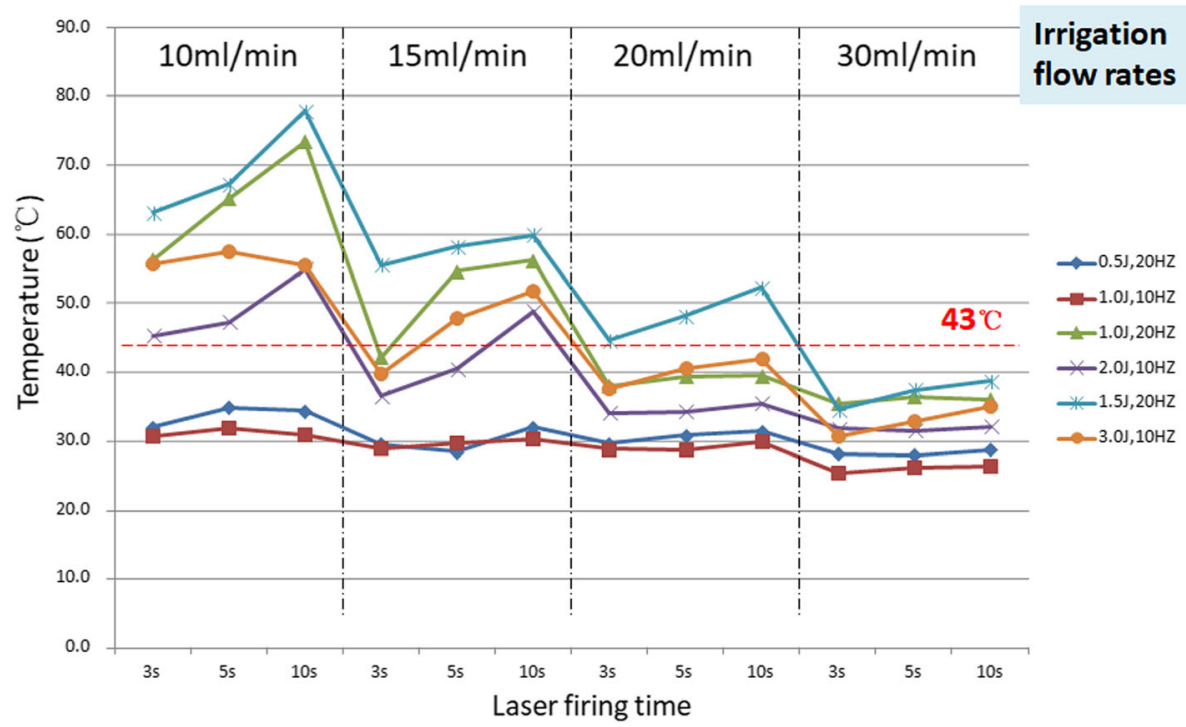

Fig. 2 Temperature curve of different laser power setting

$[3,10]$. Thermal effect stemmed from holmium laser is considered the hidden etiology for ureteral stricture.

The holmium laser is a long-wavelength pulsed laser, which can transform the energy into optomechanical/ photoacoustic and photothermal effect during calculi fragmentation $[11,12]$. The estimated mechanical effect to turn a stone into fragments is small. Most of energy will turn into the thermal effect boiling the fluid around the laser tip. Numerous studies have confirmed that significant temperature rise can occur around the fiber. Once, the temperature exceeds the "threshold" $\left(43^{\circ} \mathrm{C}\right)$, it can lead to cell damage, protein coagulation and tissue injury [13], which subsequentially progresses to scar formation and ureteral stricture. According to the relationship of the tissue thermal damage and temperature, for every $1{ }^{\circ} \mathrm{C}$ exceeds the threshold temperature, the time required to cause damage to the same number of cells will decrease by half [14]. Therefore, when the temperature reaches $56^{\circ} \mathrm{C}$, it takes only $1 \mathrm{~s}$ to cause thermal damage to the tissue. So, the thermal injury towards ureter will be easily neglected during lithotripsy procedure.

In our current study, we established an in vitro model to evaluate the thermal effect of holmium laser and the protection effect of fluid irrigation during ureteroscopic laser lithotripsy. According to our model, the temperature rise causing by laser firing depends on the laser power, working time and fluid irrigation. Higher power laser can increase temperature much more quickly. The $20 \mathrm{w}$ laser setting can increase the temperature as high as $73.5^{\circ} \mathrm{C}$ if irrigation is insufficient. Meanwhile, the high-frequency dusting model of holmium laser is much more efficient in heat production. Fluid irrigation plays an important role in regional heat dispersion. The flow rate up to $20 \mathrm{ml} / \mathrm{min}$ seems to be the optimal requirement during the laser lithotripsy while considering the intra-renal pelvis pressure and stone retropulsion at the same time. When the flow rate reaches $30 \mathrm{ml} / \mathrm{min}$, the temperature can not surpass the threshold.

Thus, we provide several feasible suggestions to prevent thermal injury during endoscopic laser lithotripsy, especially for impacted ureteral calculi. First, lithotripsy is advised start with low power setting. Generally, low power setting is sufficient to fragment majority of calculi. We recommend that the power setting should not exceed 20w for most devices. Second, apply "high-frequency" setting with more caution. Previous study have showed that dusting maneuver with higher frequency can acquire better stone free rates for renal calculi [15]. Even though the dusting maneuver is more timeconsuming and will produce more heat, the renal pelvis can disperse the heat quickly because of its larger space comparing with ureter. So, try to avoid the "high-frequency" laser parameter for stone dusting in the ureter. Third, ensure the fluid irrigation during the procedure. Irrigation flow should be sufficient to clear field of view and cool down the regional temperature. Using a smaller caliber ureteroscope accompanied with fine laser fiber can facilitate a better fluid irrigation and counter-flow. Last, for the impacted calculi, in-situ lithotripsy will be clumsy [9]. It can impair the fluid irrigation by blocking fluid circulation and cause the direct injury towards the ureter mucosa at the impacted site. So, we suggest displace the calculi to proximal portion of ureter prior to calculi fragmentation, since the dilated ureter will provide much more space for fluid irrigation and have less chance of direct injury by the laser fiber. 


\section{Conclusion}

In conclusion, we found that laser heating can cause significant temperature rise in the ureter with various laser parameters and duration of pulsing. Laser can cause irreversible thermal injury towards ureter. Thus, during clinical application of laser lithotripsy technique, caution should be taken.

\section{Abbreviations}

Holmium: YTTRIUM-ALUMINUM-GARNET; Ho: YAG

\section{Acknowledgements}

Not applicable.

\section{Authors' contributions}

$\mathrm{HL}$ designed the study and conducted the experiment. $\mathrm{BH}, \mathrm{JC}, \mathrm{CW}$ and $\mathrm{ZZ}$ performed the experiment and collect the data. $\mathrm{LL}$ drafted original manuscript. YY reviewed and edited the manuscript. $X L$ summarized the data. All authors read and approved the final manuscript.

\section{Funding}

The experimental materials used in the current study is supported by The Second Science and Technology Program (Social Development Program) from the Science and Technology Bureau of Xinchang County (2017) and Zhejiang Medicine and Health Program (2018KY853).

\section{Availability of data and materials}

The datasets used and analysed during the current study are available from the corresponding author on reasonable request.

All authors have read the paper and agree that it can be published.

\section{Ethics approval and consent to participate}

Not applicable.

\section{Consent for publication}

Not applicable.

\section{Competing interests}

The authors declare that they have no competing interests.

Received: 8 March 2020 Accepted: 8 June 2020

Published online: 15 June 2020

\section{References}

1. Oberlin DT, Flum AS, Bachrach L, Matulewicz RS, Flury SC. Contemporary surgical trends in the management of upper tract calculi. J Urol. 2015;193(3): 880-4.

2. May PC, Hsi RS, Tran H, Stoller ML, Chew BH, Chi T, et al. The morbidity of ureteral strictures in patients with prior Ureteroscopic stone surgery: multiinstitutional outcomes. J Endourol. 2018;32(4):309-14

3. Dong $H$, Peng $Y$, Li L, Gao X. Prevention strategies for ureteral stricture following ureteroscopic lithotripsy. Asian J Urol. 2018;5(2):94-100.

4. Wang XK, Jiang ZQ, Tan J, Yin GM, Huang K. Thermal effect of holmium laser lithotripsy under ureteroscopy. Chin Med J. 2019;132(16):2004-7.

5. Wollin DA, Carlos EC, Tom WR, Simmons WN, Preminger GM, Lipkin ME Effect of laser settings and irrigation rates on ureteral temperature during holmium laser lithotripsy, an in vitro model. J Endourol. 2018;32(1):59-63.

6. Maxwell AD, MacConaghy B, Harper JD, Aldoukhi AH, Hall TL, Roberts WW. Simulation of laser lithotripsy-induced heating in the urinary tract. J Endourol. 2019;33(2):113-9.

7. Cordes J, Nguyen F, Sievert KD. Factors which influence intraluminal temperature during ho:YAG-laser exposure at an in-vitro URS. Open J Urol. 2015;2015(5):34-41.

8. Pierre S, Preminger GM. Holmium laser for stone management. World J Urol. 2007;25(3):235-9.

9. Darwish AE, Gadelmoula MM, Abdelkawi IF, Abdellatif AM, Abdel-Moneim AM, Hammouda HM. Ureteral stricture after ureteroscopy for stones: a prospective study for the incidence and risk factors. Urol Ann. 2019;11(3): 276-81
10. Chen S, Zhou L, Wei T, Luo D, Jin T, Li H, et al. Comparison of holmium: YAG laser and pneumatic lithotripsy in the treatment of ureteral stones: an update meta-analysis. Urol Int. 2017;98(2):125-33.

11. Vassar GJ, Chan KF, Teichman JM, Glickman RD, Weintraub ST, Pfefer TJ, et al. Holmium: YAG lithotripsy: photothermal mechanism. J Endourol. 1999; 13(3):181-90.

12. Jacques SL. Laser-tissue interactions. Photochemical, photothermal, and photomechanical. Surg Clin North Am. 1992;72(3):531-58.

13. Winship B, Wollin D, Carlos E, Peters C, Li J, Terry R, et al. The rise and fall of high temperatures during Ureteroscopic holmium laser lithotripsy. J Endourol. 2019;33(10):794-9.

14. Sapareto SA, Dewey WC. Thermal dose determination in cancer therapy. Int J Radiat Oncol Biol Phys. 1984;10(6):787-800

15. Pietropaolo A, Jones P, Whitehurst L, Somani BK. Role of 'dusting and popdusting' using a high-powered (100 W) laser machine in the treatment of large stones ( $\geq 15 \mathrm{~mm}$ ): prospective outcomes over 16 months. Urolithiasis. 2019;47(4):391-4.

\section{Publisher's Note}

Springer Nature remains neutral with regard to jurisdictional claims in published maps and institutional affiliations.

Ready to submit your research? Choose BMC and benefit from:

- fast, convenient online submission

- thorough peer review by experienced researchers in your field

- rapid publication on acceptance

- support for research data, including large and complex data types

- gold Open Access which fosters wider collaboration and increased citations

- maximum visibility for your research: over $100 \mathrm{M}$ website views per year

At BMC, research is always in progress.

Learn more biomedcentral.com/submissions 